\title{
BILL C-92: THE CANADA PETROLEUM RESOURCES ACT
}

\author{
EDWARD J.EVANS*
}

\begin{abstract}
This paper examines the provisions of Bill C-92, the Canada Petroleum Resources Act introduced in December of 1985 to reploce the Canada Oil and Gas Act. The paper deals with such major aspects of the Act as: the repeal of the Crown share; the introduction of a new land issuance process applicable to the exploration licence, the significant discovery licence and the production licence; the elimination of retrocetive Canadian ownership rules as well as a review of the rules for the attainment of COR requirements prior to the issuance of a production licence; the restrictions placed on Ministerial discretion and the introduction of a more objective process to review Ministerial orders; changes to the royalty regime and the creation of a frontier lands registry system.
\end{abstract}

\section{INTRODUCTION}

On October 30, 1985, following the successful negotiations that led to the Atlantic and Western Accords earlier in the year, the Minister of Energy, Mines and Resources announced a comprehensive new energy policy. The legislative embodiment for this new policy is contained in Bill C-92, the Canada Petroleum Resources Act (CPRA) ${ }^{i}$ which received first reading on December 20,1985. Prepared in close consultation with the Governments of Newfoundland, Nova Scotia, the Yukon and Northwest Territories, as well as being discussed with northern native groups and with representatives of the petroleum industry, the Act will repeal the existing Canada Oil and Gas Act (COGA) ${ }^{2}$ and is designed to be a comprehensive code governing the acquisition, exploration for and production of oil and gas on federal frontier lands. It is also intended to simplify the regulatory framework and provide a consistent legislative base for oil and gas companies operating in the frontier regions. Principal elements will include:

1. a new rights issuance process based on a single, quantifiable bidding criterion;

2. limitation of the direct issuance power;

3. introduction of the exploration licence and the significant discovery licence;

4. repeal of drilling orders for commercial discoveries and the substitution of a "show cause process" for commercial discoveries;

5. repeal of production and disposition orders;

6. repeal of basic and progressive incremental royalty and the implementation of a profit sensitive royalty;

7. introduction of the $25 \%$ Investment Royalty Credit and Exploration Tax Credit;

8. limitation of the requirement for a 50\% Canadian ownership level to the production stage;

9. elimination of retroactive Canadian ownership provisions through the grandfathering of pre-March 5, 1982 discoveries;

- Solicitor, Esso Resources Canada Limited.

1. Bill C-92, 1st Sess., 33rd Parl., 33 - 34 Eliz. II, 1984 - 85. In these notes, the Bill is referred to as the "CPRA". I wish to thank the staff of and consultants to COGLA, and particularly Rowland Harrison and Wayne Londsdale, for their assistance in the preparation of this paper.

2. S.C., $1980-81-82-83$, c. 81 . In these notes, this Act is referred to as the "COGA". 
10. establishment of new rules for attainment by reasonable commercial means of required Canadian ownership levels;

11. elimination of the Crown share;

12. repeal of provisions giving preferential treatment to Crown corporations;

13. limitation of Ministerial discretion and the introduction of a more objective review process for the exercise of Ministerial discretion;

14. elimination of Ministerial approval of transfers of exploration rights; and

15. establishment of a frontier lands registry system.

\section{APPLICATION OF THE ACT}

The Act applies to all "frontier lands", ${ }^{3}$ which are defined in a manner identical to that of the Canada Lands under the Canada Oil and Gas Act as federal lands situated in the Yukon Territory, the Northwest Territories, Sable Island or offshore. ${ }^{4}$ Offshore areas are those areas not within a province extending to the greater of the outer edge of the continental margin or a distance of $\mathbf{2 0 0}$ nautical miles. The Act does not apply to federal Crown lands situated within a province such as national parks or Indian reserves. Nor does the Act attempt to deal directly with the thorny issue of aboriginal land claims, stating simply that nothing in the Act is to be construed so as to abrogate or derogate from any existing aboriginal or treaty rights of the aboriginal peoples of Canada under section 35 of the Constitution Act, 1982.

Oil and gas management in the Newfoundland offshore will be governed by Bill C-94, the Canada-Newfoundland Atlantic Accord Implementation Act. ${ }^{6}$ While Bill C-94 contains much within it to reflect the allocation of responsibilities for the Newfoundland offshore between the designated federal and provincial Ministers as well as the joint Canada-Newfoundland Offshore Petroleum Board, it incorporates the major provisions of the Canada Petroleum Resources Act. Hopefully, to provide a consistent legislative framework for exploration and development in offshore areas, changes in the CPRA will also be reflected in the Newfoundland regime.

\section{THE RIGHTS ISSUANCE PROCESS}

\section{A. ISSUANCE OF INTERESTS}

Subject to certain transitional provisions, the CPRA creates three interests, the exploration licence, the significant discovery licence and the production licence, which will replace rights formerly held under such documents as exploration agreements, leases, permits and special renewal permits. Part II of Act contains detailed legislation dealing with the process by which new interests in Crown reserve lands are to be issued. Since the terms and conditions under which new rights are issued may

3. CPRA, supra n. 1 at s. 5.

4. Id. at s. 2.

5. Id. at s. 3.

6. 1st Sess., 33rd Parl., 33 - 34 - 35 Eliz. II, 1984 - 85 - 86. 
affect the economic value realized for a resource and influence the timing, rate and geographic location of activity, they are of vital importance. The Canada Oil and Gas Act provided broad Ministerial discretion in its rights issuance process, allowing the Minister to issue new rights either through competitive calls for proposals or through direct issuance. The Minister was allowed to select any proposal submitted and to take into account any factors considered appropriate in the public interest when making a selection. ${ }^{7}$ Such a process is similar to the concessionary system used in some petroleum producing countries where rights are issued on the basis of a subjective evaluation of multiple criteria including work commitments, profit sharing, industrial benefits, and degree of domestic ownership. This system stands in contrast to the auction system most commonly used in the western producing provinces and the United States in which rights are issued to the highest bidder, normally on the basis of a cash bid. The virtues of the auction system are its simplicity, consistency and competitiveness. Under such a system, a company bidding for a new parcel can generally determine how the winning bid was selected.

The federal government has made it clear that it finds the arguments on the side of an auction system compelling, but that it also desires to maintain considerable flexibility in the selection of an appropriate bidding criterion to fit the circumstances of a particular call for proposals. Accordingly, except in limited circumstances, the Canada Petroleum Resources Act requires that the issuance of Crown reserve lands be initiated by a published call for bids on specific parcels of Crown reserve. As is the case in the western producing provinces, the Minister may consider posting any lands nominated by industry. ${ }^{8}$ In order to enhance the objectivity of the selection process, the call for bids must specify the sole criterion that the Minister will apply in assessing bids submitted in response to the call.9 The government has indicated that this criterion may be the payment of a cash bonus, a specified work program or a cash value work program. The Minister maintains discretion in the selection of the appropriate bidding criterion. It has been suggested that the key determinants of this choice will be the geological prospectivity of the lands and the policy objectives of the region: for example, where Crown reserve lands are issued in close proximity to an existing commercial discovery, a cash bonus may be appropriate, while a dollar value work commitment may be more suitable for previously unexplored areas.

As well as designating the interest to be issued, the frontier lands to which it is to apply and the sole bidding criterion, the call for bids also allows the Minister to specify the geological formations and substances to which the interest to be issued will apply. ${ }^{10}$ The Act will allow the restriction of interests by geological formation or substances, but not retroactively, so that the holders of existing interests or interests which are transformed into the new licences under the Act will not be forced to surrender substances or geological formations."
7. COGA, supra n. 2 at ss. $11,12,14$.
8. CPRA, supre n. 1 at s-ss. 14(1), (2).
9. Id. at s-s. 14(3).
10. Id.
11. Id. at 3-ss. 13 (2), (3). 
The Minister is also given the discretion to specify in the call for bids any terms and conditions that a bidder must satisfy in order to be considered. ${ }^{12}$ These pre-bid qualifications must be met or accepted by all persons wishing to bid and could relate to such items as minimum Canadian Ownership Rates (COR), work programs, specific native and northern concerns or benefit plans. As presently structured, therefore, the Act would allow the Minister the discretion to prevent certain classes of potential bidders, such as entities having a low Canadian Ownership Rate, from bidding on specific parcels of Crown reserve, a situation which may be of considerable concern to potential investors and which would not seem to accord with the stated policy objective of instituting a non-discriminatory rights issuance process. The Cabinet is also given the authority to standardize the bidding criterion or pre-bid qualifications either generally or for a particular region. ${ }^{3}$ This may prove particularly effective in areas where FederalProvincial Accords are in place.

The Act provides for a minimum of 120 days in which to submit bids after publication of the call. ${ }^{14}$ While the Minister is not required to issue an interest as a result of a call for bids, where an interest has not been awarded within six months after the close of bids, a new call must be issued. ${ }^{15}$ This six month sunset provision is intended to deal with situations in which there is difficulty assessing work programs or in which no tenders are received, but its length seems at variance with the stated intention of developing a single, quantifiable bidding criterion with rights going to the best bid. To help ensure objectivity, the selection must be made on the basis of the criterion specified in the call. An interest can only be issued to a person who submitted a bid in response to the call and then only if the bid satisfied the terms and conditions contained in the call. Further, both the terms and conditions of the winning bid and of any interest issued as a result of the call must be published by the Minister. The interest itself must be "substantially" consistent with the terms and conditions specified in the call. ${ }^{16}$ The scope of the discretion given to the Minister by the use of the words "substantially consistent" is unclear, but presumably would not include any material deviations from the requirements of the call, since the Act does not contemplate a subsequent negotiation phase with the successful bidder.

\section{B. DIRECT ISSUANCE}

While an exploration licence, significant discovery licence or a production licence may be issued for Crown reserve lands after a call for bids, the Minister's controversial power under the Canada Oil and Gas Act to issue interests directly from Crown reserve lands without employing the bidding process has been restricted to two exceptional circumstances. ${ }^{17}$ The first is at the request of an interest owner within one year of the time after which

12. Id. at s-s. 14(3).

13. Id. at s. 20.

14. Id. at s-s. 14(4).

15. Id. at s. 16.

16. Id. at s. 15 .

17. Id. at s. 17. 
the frontier lands in question became Crown reserve through error or inadvertence. The second exception permits the interest owner and the Minister to negotiate an exchange of rights. While the circumstances in which this exchange may take place are not limited by the Act, an exchange may be possible in the event of an international boundary dispute or an environmental problem which has led to an order prohibiting activities under section 12. The Minister is required to disclose any proposed direct issuance through publication of a notice 90 days prior to issuing the interest, setting out its terms and conditions. Presumably, representations as to the appropriateness of such a decision may be made during this period. The Act does not, however, provide a process whereby the Minister's decision may be reviewed.

\section{EXPLORATION LICENCES}

Once a call for bids has been made and a winning bid selected, the negotiated exploration agreement under the Canada Oil and Gas Act has been replaced by an exploration licence which, like the exploration agreement, confers a non-exclusive right to explore for petroleum as well as exclusive rights to drill, test and develop the frontier lands and the exclusive right to obtain a production licence provided the interest owner qualifies. 18

In an effort to balance the interest owner's concern that the term of the exploration licence be sufficient to permit it to evaluate properly resource potential against the Crown's desire to promote exploration by the licence holder and to ensure that rights are recycled within reasonable periods of time, exploration licences will be issued for a non-renewable term not to exceed nine years from the effective date specified in the licence. On expiration of an exploration licence, any frontier lands not subject to a production licence or a significant discovery licence revert to Crown reserve. There is, however, provision for the continuation of an exploration licence at the end of its term if a well, or a well substituted for that well, is being drilled and for so long thereafter as may be necessary to determine the existence of a significant discovery based on the results of the well. ${ }^{19}$

Because at the exploration stage ownership patterns are rarely homogeneous, in the case only of an exploration licence, the Act allows the participants to hold shares with respect to a portion only of the frontier lands subject to the licence, thereby allowing the coexistence of divided and undivided ownership in a single exploration licence..$^{20}$ The Act distinguishes between "interest holders" who are the registered holders of an interest or a share of an interest, and an "interest owner" which is the collective group of interest holders who hold all the shares of an interest. ${ }^{21}$ Application for a significant discovery licence may be made by the interest holder of the exploration licence or of a share of the exploration licence. The Minister is required to issue a significant discovery licence to such a holder for all portions of the significant discovery subject to the explora-

18. Id. at s. 22.

19. Id. at ss. 26, 27.

20. Id. at s. 23.

21. Id. at s. 2. 
tion licence or the share of the exploration licence. ${ }^{2}$ In this way, the holder of a divided share who feels its reserves merit a greater undivided interest of the significant discovery licence will not interfere with the licence issuing process, since a separate significant discovery licence may be issued for each divided share.

Existing exploration agreements, or EAs, for which negotiations have been completed prior to December 20,1985 must be renegotiated on their expiry for a further term not to exceed four years. ${ }^{23}$ Presumably, factors the Minister would take into account in any renegotiation process would be whether existing commitments had been met and whether the exploration agreement was in good standing. Failure to renegotiate an EA results in the deemed surrender of the frontier lands and their reversion to Crown reserve. In prescribed areas, where an exploration agreement has been renegotiated, the Minister has the discretion to extend its term. This may be utilized where a land issuance moratorium is in effect due to native land claims.

The Act allows the Minister and an interest owner to amend by agreement any provision of an exploration licence, including the power to add other frontier lands to the area held under the exploration licence. This may allow for the grouping of expenditures by an interest owner who holds two or more exploration licences. The discretion given to the Minister is limited by the requirement that the amendment must not be inconsistent with the Act or the Regulations. Nor can the Minister include Crown reserve lands unless the call for bids process is utilized or unless the Minister would otherwise be able to employ the direct issuance power (such as in the case of error, inadvertence or an exchange of lands under section $17)$ and prior notice has been published. ${ }^{24}$

The Minister is also given the discretion to consolidate two or more exploration licences into a single exploration licence subject to any terms and conditions agreed to by the Minister and the relevant interest owners. There is no requirement that the licences be adjoining, nor does there exist the same express limitation that the terms and conditions agreed to must be consistent with the Act or the Regulations. ${ }^{23}$ Again, this is a possible method of grouping expenditures where more than one interest owner is involved, or of raising Canadian ownership levels prior to application for a production licence.

\section{SIGNIFICANT DISCOVERIES}

Since exploration licences are non-renewable, the Act introduces a new form of land tenure called the significant discovery licence by which an interest owner may retain, prior to issuance of a production licence, those frontier lands to which the Minister has reasonable grounds to believe that a significant discovery extends. "Significant discovery" is defined as a discovery indicated by the first well on a geological feature that demon-

\footnotetext{
22. Id. at s. 30.

23. Id. at s-s. 26(3).

24. Id. at s. 25 .

25. Id. at s-s. 25(3).
} 
strates by flow testing the existence of hydrocarbons and suggests the existence of an accumulation that has potential for sustained production. ${ }^{25}$ Where a significant discovery has been made on any frontier lands subject to an interest, the Minister is required on the application of the holder of the interest or share to make a written declaration of significant discovery with respect to those frontier lands, or has the discretion to make such a declaration on his or her own initiative, subject to the hearing and judicial review provisions of section 106 of the Act. ${ }^{27}$

Once a significant discovery declaration has been made, the Minister is then given the discretion, again subject to a hearing and judicial review, to amend or revoke the declaration where, based on the results of further drilling, the Minister has reasonable grounds to believe that a discovery is not significant or that the lands to which the significant discovery extends differ from the significant discovery area described in the declaration. ${ }^{23} \mathrm{On}$ the issuance of a significant discovery licence, any exploration licence ceases to have effect in relation to that significant discovery area. ${ }^{29}$ However, for holders of existing interests, the change to a significant discovery licence will not be restricted by substance or horizon since this form of relinquishment will be retained only for future interests issued out of Crown reserve. The ability to amend or revoke a declaration of significant discovery is of importance to the holder of a significant discovery licence since any amendment or revocation will trigger a corresponding decrease and possible reversion to Crown reserve of the frontier lands subject to the significant discovery licence. Alternatively, any increase in the significant discovery area allows the inclusion of frontier lands held under an exploration licence at the time of the amendment. To allow interest owners a more secure form of tenure, the Minister's discretion to amend or revoke a significant discovery declaration has been limited. Section 28 provides that such a declaration may not be revoked or amended to decrease the significant discovery area at a date earlier than the date on which the exploration licence from which the significant discovery licence was issued expires or, in the case of a significant discovery licence issued from Crown reserve lands, three years after the effective date of the licence.

Once a significant discovery declaration is in force, the Minister is obligated to issue a significant discovery licence to the holder of an interest or divided share who has made application for one in respect of all portions of the significant discovery area that are subject to the exploration licence or share. The Minister may also issue a significant discovery licence for Crown reserve lands within the significant discovery area, but only after observing the call for bids process previously described and selecting a bid in accordance with the Act. ${ }^{30}$
26. Id. at s. 2.
27. Id. at s. 28.
28. Id. at s-s. 28(4).
29. Id. at s. 32.
30. Id. at s. 30. 
The significant discovery licence itself grants the same rights as does an exploration licence but does not have a limited term. ${ }^{31}$ Recognizing that a considerable period of time may elapse between the drilling of a discovery well and the accumulation of sufficient reserves and other factors that would justify proceeding to the production licence stage, the significant discovery licence subsists so long as the declaration of significant discovery remains in effect with respect to those frontier lands. On the expiry of a significant discovery licence, any frontier lands which are not subject to a production licence become Crown reserve. ${ }^{32}$

\section{E. DRILLING ORDERS}

While the significant discovery provides a mechanism for holding title prior to production, it is also a method by which the Crown may spur development through the issuance of drilling orders. Under the Canada Oil and Gas Act, the Minister was granted the extraordinary power to order the drilling of up to three wells simultaneously on a significant discovery area. ${ }^{33}$ Drilling orders for significant discoveries have been retained under the Canada Petroleum Resources Act, but their scope has been limited, including a reduction of the maximum number of wells that can be ordered drilled at any one time. Under the Act, at any time after making a declaration of significant discovery, the Minister may order the interest owner of any interest (not simply the owner of a significant discovery licence) in any portion of a significant discovery area to drill a well on that significant discovery. ${ }^{34}$ Since the Act provides that drilling must be in accordance with the direction set out in the order, it is conceivable that such an order may contain detailed requirements with respect to location, drilling depths, testing programs, etc. Because no drilling order may be issued within three years immediately following the well termination date of the well indicating a significant discovery and because the drilling order cannot require the commencement of the well until one year after it is made, effectively an interest owner will not be subject to mandatory drilling requirements during the first four years following the date on which the well was abandoned, completed or suspended in accordance with any applicable drilling regulations. Nor can an interest owner who has completed a well within the previous six months be made subject to another drilling order. Unlike the COGA, no order may require an interest owner to drill more than one well at a time. The Minister's discretion to issue such an order is itself subject to the hearing and judicial review process under section 106 of the Act. Non-compliance with a drilling order may cause the Minister to invoke the default provisions of section 105 leading to cancellation of an interest following a 90-day period requiring compliance. An interest owner who does not wish to comply with such an order has the alternative of surrendering its interest in accordance with the provisions of section 11 , subject to any accrued liabilities to the Crown.

31. Id. at s. 29.

32. Id. at s. 32.

33. COGA, supran. 2 at s-s. $45(1)$.

34. CPRA, supra n. 1 at s. 33. 
Since the significant discovery licence is intended to be a method of maintaining title prior to the production stage, no provision has been made for amendment or consolidation of significant discovery licences.

\section{F. COMMERCIAL DISCOVERIES}

Neither an exploration licence nor a significant discovery licence grants the right to produce any petroleum discovered on frontier lands, only conferring on its holder the exclusive right to obtain a production licence, subject to compliance with the other provisions of the Act. ${ }^{35}$ Before such a production licence can be issued, the Minister must be satisfied of the existence of a commercial discovery and Canadian ownership requirements must be taken into consideration.

The Act defines "commercial discovery" as a discovery of petroleum that has been demonstrated to contain petroleum reserves that justify the investment of capital and effort to bring the discovery to production. ${ }^{36} \mathrm{As}$ was the case with respect to a significant discovery, the Minister is required to make a declaration of commercial discovery on application by an interest holder (or holder of a divided share of an exploration licence), or may do so on his or her own initiative, in respect of frontier lands to which there are reasonable grounds to believe that a commercial discovery extends. Like a declaration of significant discovery, once a commercial discovery declaration has been made it may be revoked or amended to increase or decrease the lands to which it applies where further drilling indicates to the Minister that there are reasonable grounds to believe that a discovery is not commercial or that the frontier lands to which the commercial discovery extends differ from the previously-declared commercial discovery area. Similarly, adverse Ministerial decisions with respect to the declaration, amendment or revocation of a commercial discovery are all subject to the hearing and judicial review provisions of section 106."

\section{G. DEVELOPMENT ORDERS}

The Minister's discretion under the Canada Oil and Gas Act to order the drilling of an unlimited number of wells on a commercial discovery area and to commence such drilling within the periods and at the times and places the Minister specified" has been repealed and replaced by a "show cause process" leading to a fixed term development order. ${ }^{39}$ Once the Minister has made a declaration of commercial discovery, the show cause process is commenced by issuance of a notice to the owner of any interest (including an exploration licence, significant discovery licence or production licence) in the commercial discovery area where commercial production has not commenced stating that an order may be made reducing the term of that interest after a period of not less than six months. It is unclear from the wording of this section whether such an order may be made if

35. Id. at ss. $22,29$.

36. Id. at s. 2.

37. Id. at s. 35.

38. COGA, supra n. 2 at s. 47.

39. CPRA, supra n. 1 at s. 36. 
[VOL. XXV, NO. 1

there is commercial production from another portion of the commercial discovery area. Although an interest owner is given the opportunity to make submissions to the Minister showing cause why such a fixed term order should not be made, the Minister is given wide discretion to disregard these submissions if of the opinion that the fixed term order is in the public interest. Where the Minister is of the opinion that a fixed term order is in the public interest, the term of any interest in relation to any portion of the commercial discovery area (but not outside of that area) may be reduced to three years or such longer period as may be specified. To prevent protracted delays and uncertainties, the Minister is required to make this order within six months after the period specified in the initial notice, failing which the entire process must be reinitiated. At the end of the period specified in the order, the interest will terminate unless commercial production of petroleum on the frontier lands in question has commenced. If production does commence, the order is deemed to have been vacated and the normal rights associated with the interest continue to apply. The development order may be extended or revoked at any time by the Minister and is subject to the hearing and judicial review process established by section 106.

\section{H. PRODUCTION LICENCES}

To produce oil and gas from frontier lands other than for limited purposes associated with exploration, drilling or development, an interest owner will require a production licence which confers the same rights as does an exploration licence as well as the exclusive right to produce petroleum from the frontier lands, and which grants title to the petroleum so produced..$^{\circ}$ The term of a production licence has been increased from 10 years to 25 years from the date of issuance and so long thereafter as commercial production of petroleum continues. To deal with the problem of intermittent or shut-in production, the Minister is also given the discretion to extend the term where he or she has reasonable grounds to believe that commercial production from the lands will recommence."

On issuance of a production licence, all other interests in those frontier lands included in the licence cease to have effect..$^{2}$ As was the case in significant discoveries, a production licence may be amended or revoked with the commercial discovery area by the results of further drilling. ${ }^{3}$ Also like the significant discovery licence, the direct issuance power has been curtailed and a production licence may be issued with respect to Crown reserve lands only in accordance with the bidding process established by the Act. ${ }^{4}$

Provided the owner of an exploration or significant discovery licence meets the Canadian ownership requirements of the Act, it is entitled to the issuance of a production licence as of right on application. The Act also gives the Minister the discretion to issue one production licence to an
40. Id. at s. 37.
41. Id. at s. 41.
42. Id. at s. 42.
43. Id. at s-s. 35(3) and s. 40.
44. Id. at s. 38. 
interest owner for two or more commercial discovery areas or to two or more interest owners for one or more commercial discovery areas. Similarly, the Minister may allow interest owners to consolidate production licences subject to such terms and conditions as may be agreed. ${ }^{45}$ The Act does not require that the discoveries or licences be adjoining. This ability to pool commercial discovery areas or consolidate production licences allows interest owners greater flexibility in meeting the Canadian ownership requirements of the Act. By pooling working interests within one or more commercial discovery areas, the interest owners of exploration or significant discovery licences may be able to improve the Canadian Ownership Rate of individual discoveries to meet the 50\% COR required by the Act prior to issuance of a production licence. This ability to consolidate also allows several discoveries or licences to be unitized and developed as a single economic unit under a single production licence with the same terms and conditions.

\section{PRODUCTION ORDERS}

Under the Canada Oil and Gas Act, the Minister was given the extraordinary power to order, without compensation, alterations in the rate of production from frontier areas and the delivery of production to a particular market at specific rates and prices. ${ }^{46}$ While legislation establishing such extraordinary powers in times of emergency may be within the constitutional ambit of federal authority, production and disposition orders do not form a part of the Canada Petroleum Resources Act.

\section{CANADIANIZATION}

\section{A. CANADIAN OWNERSHIP}

While the Act will retain the requirement of a 50\% Canadian ownership level at the production stage, some of the more onerous and retroactive aspects of the Canada Oil and Gas Act have been repealed. Because the Canada Oil and Gas Act was retroactive in its effect, the requirement for a $50 \%$ COR extended to discoveries made before the enactment of the legislation on March 5, 1982. Similarly, under the Canada Oil and Gas Act, if a project had a COR of less than $50 \%$, the federal government was able to expropriate, without compensation, an interest in the project sufficient to raise the COR to the required level.

Under the Canada Petroleum Resources Act, before granting a production licence, the Minister must also be concerned with the citizenship of an individual interest holder or the Canadian ownership of a corporate interest holder. To qualify, an individual interest holder must be either a Canadian citizen ordinarily resident in Canada or a permanent resident unless that person has been ordinarily resident in Canada for more than one year after the time of first becoming eligible to apply for Canadian citizenship. The restrictions on permanent residents, however, will not apply until after March 5,1987, to be consistent with the former provisions of the Canada Oil and Gas Act which allowed permanent residents five

45. Id. at s. 38.

46. COGA, supra n. 2 at s. 48. 
[VOL. XXV, NO. 1

years to apply for Canadian citizenship. Production licences may be issued only to such individuals or to corporations incorporated in Canada. ${ }^{47}$ Foreign individuals or corporations will not be able, therefore, to hold directly shares in a production licence.

Even if this requirement is met, the Minister is prohibited from issuing a production licence unless satisfied that the COR of the interest owner of the production licence on the date of issuance would be not less than $50 \%$. ${ }^{43}$ This general rule is subject to the major exception that COR requirements apply only to production licences relating to discovery wells drilled after the enactment of the Canadian ownership provisions of the Canada Oil and Gas Act on March 5, 1982, whether or not that discovery was determined to be significant or commercial before the coming into force of the Canada Petroleum Resources Act. ${ }^{49}$ The corporate interest holder of such discoveries must meet the less stringent requirements set out in subparagraphs 54(2)(c)(i), (ii) or (iii) of the Canada Oil and Gas Land Regulations, with the effect that no production licence for such pre-March 5, 1982 discoveries will be granted to a corporation unless the Minister is satisfied:

(i) that at least 50 percent of the issued shares of the corporation is beneficially owned by

(A) persons who are Canadian citizens,

(B) corporations that meet the qualifications set out in subparagraph (ii), or

(C) both such persons and corporations;

(ii) that the shares of the corporation are listed on a recognized Canadian stock exchange and that Canadians will have an opportunity of participating in the financing and ownership of the corporation; or

(iii) that the shares of the corporation are wholly owned by a corporation that meets the qualifications outlined in subparagraph (i) or (ii).

The process by which a Canadian Ownership Rate is determined does not form part of the Act but is delegated to the complex rules established under the Canadian Ownership and Control Determination Act. However, the Act does specify that where an interest owner comprises several entities, the Canadian Ownership Rate of such an owner is the sum of the products obtained by multiplying the COR of each holder by its share in the production licence. The Act also establishes a broad and unspecified anti-avoidance provision in which the Minister is given the discretion to determine COR in accordance with such criteria as he or she considers appropriate where it "appears" to the Minister that a COR cannot reasonably be determined by applying the rules set out in the Act or regulations. This discretion may be exercised either on a case-by-case basis or by a class of cases. ${ }^{30}$ Different (possibly simpler) methods for the calculation of the level of Canadian ownership or the determination of

47. CPRA, supra n. 1 at s. 44.

48. Id. at s. 46.

49. Id. at s. 53.

50. Id. at s. 52. 
beneficial ownership of a production licence may also be established by regulation under the Act. Presently, the Act does not specifically deal with the situation where the beneficial ownership of a production licence does not correspond with registered ownership."

Under the Canada Oil and Gas Act, if an interest owner was unable to meet the $50 \%$ Canadian ownership level, the Crown reserved a share in the production licence equal to the difference between this $50 \%$ and the actual Canadian Ownership Rate of the interest owner as determined by the Minister. This interest was forfeited to the Crown without compensation and disposed of by public tender to a party with a $75 \%$ COR. The actions of one member of a group could affect all of its members since COR levels were checked at ten year intervals when the production licence was renewed. ${ }^{\text {s }}$

The regime established by the Canada Petroleum Resources Act removes most of the more objectionable provisions of the COGA with respect to Canadian ownership. Where it is anticipated that the Canadian Ownership Rate will not meet the required $50 \%$ level, the interest owner must now at the time of filing a development plan, submit a plan satisfactory to the Minister providing for the attainment by reasonable commercial means of a Canadian ownership level of not less than $50 \%$ by the time of the issuance of the production licence. Those who can establish to the satisfaction of the Minister that the required COR level has already been met will not be required to submit such a COR plan. ${ }^{33}$ If at the time a production licence is issued the required 50\% COR level has not been reached despite diligent adherence to the agreed Canadian ownership plan, the Minister may either waive the COR requirements subject to appropriate terms and conditions respecting attempts to raise COR or, more probably, require a sale by public tender of a share of the production licence sufficient to raise the Canadian Ownership Rate of the interest owner to $50 \%$ if the share was acquired by a person having a COR of $75 \%$.

The sale by public tender is envisaged as a private sale required by legislation in which the terms and conditions of the sale will be specified by the interest holders required to divest themselves of their interest. The closing date of the sale (not later than six months after issuance of the production licence) is provided for by legislation, as are the qualifications of eligible purchasers which will be determined by the Minister. Interest owners will be allowed to specify the terms and conditions that a successful bidder must meet, which may include acceptance of the terms of and novation into existing operating agreements. The Minister's determination of the eligibility of any particular purchaser may, for example, include a minimum level of Canadian ownership. These terms, conditions, qualifications and any other matter that is relevant to the sale are to be specified in the invitation to tender.

51. Id. at s. 51 .

52. COGA, supra n. 2 at ss. $23,25$.

53. CPRA, supra n. 1 at s. 47.

54. Id. at ss. $48,49$. 
[VOL. XXV, NO. 1

The share must then be sold to a person who meets the qualifications specified in the invitation to tender and will be subject to a reserve bid equal to the fair market value of the share determined in a prescribed manner.s While the method of determining fair market value has yet to be prescribed by regulation, it is the government's announced intention that the reserve bid will be established through independent, third-party evaluation. If the share is not sold by public tender, a designated Crown corporation will be given the option to purchase it at the reserve price for a period of 60 days after the closing date of submission of tenders. No provision is made in the Act which would require a subsequent offering of the interest if this option is not exercised.

Unlike the Canada Oil and Gas Act, no holder of a share of any production licence will be required to divest itself of any portion of that share if its Canadian Ownership Rate is 50\% or more. Nor will the COR of interest owners under the Canada Petroleum Resources Act be subject to periodic review after the issuance of a production licence except in the event of disposition. Those holders of a share who are required to transfer an interest pursuant to a sale must do so in the proportions agreed upon by them or, in the absence of agreement, in the proportions determined by regulation. Clearly, this is an area that will generate considerable negotiation among the parties to future joint ventures. Canadian ownership plans may well be restricted to those of low-COR entities who must increase their Canadian Ownership Rate to the required 50\% level necessary to prevent mandatory divestiture.

\section{B. THE CROWN SHARE}

One of the most controversial measures contained in the Canada Oil and Gas Act was the reservation to the federal government of a 25\% Crown share carved out of all interests held in the frontier. ${ }^{36}$ This measure, by retroactively changing the rules under which investors had committed themselves to expenditure on Canada's frontier, caused considerable friction and erosion of investor confidence in Canada. Under the Canada Petroleum Resources Act, the Crown share is abrogated."

\section{THE ROLE OF CROWN CORPORATIONS}

The Canada Oil and Gas Act gave designated Crown corporations special rights in relation to interests acquired in the exercise of the Crown share and through the back-in provisions of the former regulations. A designated Crown corporation was entitled to receive any exploration, development or production information as well as to participate and vote the Crown share in all operating decisions even prior to conversion of the Crown's carried interest to a working interest. Moreover, the designated Crown corporation could rely on the government to impose an operating agreement on its partners should it fail to obtain one through negotiation.s8

55. Id. at s-5. 49(3).

56. COGA, supre n. 2 at 3. 27.

57. CPRA, supra n. 1 at s. 117.

58. COGA, supre n. 2 at ss. $33,34,35$. 
Under the Canada Petroleum Resources Act, it is clear that the preferential treatment accorded to Crown corporations has changed and that such companies must conduct their affairs according to the same rules as private sector companies. Under the Act, all rights of Petro-Canada to acquire further interests or shares in interests under the Canada Oil and Gas Regulations are abrogated as of March 5, 1982. The company's right to exercise its preferential rights of selection of Crown reserve land under these Regulations is also terminated effective April 30, 1980.9 ${ }^{99}$ There exists no provision for the imposition of an operator who does not possess a working interest in the frontier lands in question.

\section{CANADA BENEFITS}

Section 121 of the Act also amends the Oil and Gas Production and Conservation Act, including detailed provisions for the preparation and approval of development plans which require a Canada benefits plan to be submitted for approval by the Minister unless waived. The benefits plan is to provide for the employment of Canadians and to provide Canadian manufacturers, consultants, contractors and service companies with a full and fair opportunity to participate on a competitive basis in the supply of goods and services. The Minister is given the discretion to require that a benefits plan contain affirmative action programs, including provisions to ensure that disadvantaged individuals or groups have access to training and employment opportunities and to enable such individuals or groups to participate in the supply of goods and services.

\section{TRANSFER AND ASSIGNMENT}

Under section 52 of the Canada Oil and Gas Act, any proposed disposition of a share of an interest required the previous approval of the Minister. At the exploration stage, the approval process prevented a shifting of Petroleum Incentive Program payments to non-eligible companies while, at the production stage, the government's principal concern was with the maintenance of Canadian ownership levels. With the elimination of the Petroleum Incentive Program, the need for such prior approval has disappeared. Under the Canada Petroleum Resources Act, a broadly-phrased disclosure requirement for transfers or assignments of exploration interests has been substituted which will serve as a base for monitoring Canadianization. Where an interest holder enters into an agreement or arrangement which results or may result in the disposition of a share of an interest, the holder is required to give the Minister notice together with a summary of the terms and conditions of the agreement or arrangement. ${ }^{.0}$

Because of the government's concern with Canadian ownership at the production stage, any agreement or arrangement which may result in the disposition of a share in a production licence will still require prior Ministerial approval. The Minister is given the discretion where a proposed transferee does not possess the required qualifications for a production

59. CPRA, supra n. 1 at s. 112.

60. Id. at s. 85 . 
licence or, broadly, on any other grounds relating to Canadian ownership, to disapprove the arrangement, approve it subject to terms and conditions relating to the Canadian Ownership Rate (presumably the implementation of a plan to raise the COR of the production licence), or approve it. The agreement or arrangement has no force or effect until such approval is obtained. A security arrangement which may result in the transfer of a share of a production licence must, therefore, obtain the prior approval of the Minister. This clearly applies to section 177 security under the Bank Act or to an instrument granting a fixed charge on a share of a production licence, but would also be applicable to a floating charge which may attach on crystallization to a share of a production licence. No further approval is required, however, where the transfer results from the realization by a lender of its security under a previously-approved loan agreement. ${ }^{\text {b1 }}$

At present, a transferee or assignee who has acquired a right in a production licence through a takeover which has been approved by Investment Canada would also require approval by the Minister. In the interests of efficiency, it would be preferable to have a prospective investor be required to deal only with one government agency in the approval process.

\section{REGISTRATION SYSTEM}

To facilitate conveyancing of interests and financing, the Act has established a detailed system of public registration of interests and transactions relating to interests modelled on the registration system for Crown leases under the Alberta Mines and Minerals Act. Under the system, no document other than an interest or an instrument may be registered. "Interests" are defined broadly to mean any former exploration agreement, former lease, former permit, former special renewal permit, exploration licence, production licence or significant discovery licence. "Instruments" are divided into three major categories: firstly, transfers of interests or shares in interests; secondly, documents relating to security notices founded on security interests; and, thirdly, postponements and discharges of postponements of operator's liens. A "security interest" is generally defined as a charge to secure the payment of an indebtedness, the security of a corporation or the performance of the obligations of a guarantor that includes a security given under section 177 of the Bank Act but does not include an operator's lien. ${ }^{63}$

The Act provides that instruments may not be registered unless submitted in the prescribed form, contain the required information and meet all the other requirements of the Act. This may lead to future difficulties, including a loss of priority, since the Act contains no saving provision relating to defects of form. Requirements for the contents of security notices are also specified. ${ }^{4}$ Transfers of a production licence or shares of a production licence are not, of course, registrable until approved

61. Id. at s. 86.

62. Id. at s. 88 .

63. Id. at s. 84 .

64. Id. at s. 88 . 
by the Minister in accordance with the Act. ${ }^{6 s}$ Any security notices which may be registered against present interests will be automatically carried forward to the new significant discovery licences and production licences when issued to avoid the legal uncertainties associated with a transition to a new form of land tenure. ${ }^{\infty}$

Under the system, the Registrar accepts for registration documents that are in the prescribed form and registers them in chronological order as received. Once registered, the instrument has priority by time of registration over non-registered or subsequently registered instruments regardless of their date of acquisition and over any right in relation to an interest for which an instrument may not be registered acquired after the time of registration. ${ }^{\circ}$ The priority provisions are, therefore, very broad in dealing with both registrable instruments and unregistrable rights. In a way similar to a Torrens system of land registration, those who propose to deal with an interest must first consult the register to determine the presence of any preexisting rights and must then register their interest if allowed by the Act in order to preserve their priority.

Registration of an instrument is deemed to constitute actual notice of the instrument to all persons as of the time of registration. In the case of a security notice, registration is also deemed to be actual notice of the contents of the document giving rise to the security notice to all persons who may serve a demand for information (generally the holders of an interest, debtors or guarantors) ${ }^{68}$ Because of the wording of this section and of section 95 which defines who may serve a demand for information, this constructive notice of the contents of the document may not apply to prospective assignees in the case of restrictions on transfer contained in the documents giving rise to the security notice. The difficulty that a prospective assignee faces in reviewing the contents of a security notice to determine the existence of any negative pledges is that, under section 95 , the only method of obtaining the documents giving rise to the security notice is the cumbersome one of obtaining leave to do so from a Court.

Transitional provisions provide for the registration and priority of preregistration system transactions by the date the right was acquired if the appropriate instrument is registered not later than 180 days after coming into force of this part of the Act. ${ }^{69}$ Failure to register an instrument within this grace period means that priority will be determined by date of registration. Such instruments must be accompanied by a statutory declaration of the person claiming the right attesting to the time of its acquisition. To prevent abuses in the case of such pre-registration system transactions, no person who acquired a pre-registration system right will be able to claim priority by registration within the grace period over the holder of another pre-registration system right who does not register within the grace period if, at the time of acquisition, there existed actual knowledge of the other right.
65. Id. at s. 89.
66. Id. at s. 91 .
67. Id. at s. 94 .
68. Id. at s. 93.
69. Id. at s-s. 94(2). 
Frontier operators who sometimes advance large sums on behalf of their joint operators in the belief that they will be reimbursed later on the strength of their operator's lien will also be protected. An "operator's lien" is defined in the Act and is, briefly, any charge on, or right in relation to, an interest or share arising under contract which requires a holder to make payments to an operator to cover advances made by that operator for costs relating to any exploration, development or production work or activity. Operator's liens need not be registered and have priority over any other right in respect of which an instrument may be registered, whether the lien was acquired before or after the right, unless a postponement of the lien is registered. ${ }^{*}$ It is unclear whether the discharge of such a postponement would re-establish the priority of the operator's lien in the face of intervening rights.

Similar to the provisions that exist under the Alberta Mines and Minerals Act, section 95 of the CPRA delineates the classes of persons who may serve a demand for information relating to a security notice on a secured party. Such persons include the holders of an interest or share of an interest, the person from whom the security interest was acquired, another secured party, or'persons who obtain leave from a Court. The secured party then has 15 days to inform the person serving the demand notice of the place where the documents specified are located and available for examination and to make these documents or copies of them available for examination during normal business hours. Failure to comply with the demand for information allows the person making the demand to make a Court application for an order requiring compliance. Failure to comply with the Court order, in turn, allows the Court to direct cancellation of the registration of a security notice or to make another order to ensure compliance.

The Act provides a method of cancelling security notices very similar to that available for caveats under a land titles system." Any person who may serve a demand for information may also serve on a secured party a notice to take proceedings which obliges the secured party to apply to a Court of competent jurisdiction within 60 days for an order substantiating the security interest. Alternatively, where even more haste is required, the party may itself commence proceedings in a Court requiring the secured party to show cause why the registration of the security notice should not be cancelled. A Court may shorten or extend the 60-day period. The security notice will then be cancelled on submission to the Registrar of a statutory declaration stating that a notice to take proceedings was served and that no application was commenced or that an application was dismissed or discontinued. Nuisance registrations are dealt with by providing that security notices which have been cancelled may be registered again only with leave of a Court. The Act provides for regulations to be issued prescribing Courts having jurisdiction over the frontier lands, which it has been proposed will be either Courts adjacent to the lands or Courts determined by agreement among interest owners. ${ }^{2}$

70. Id. at s-s. 94(5).

71. Id. at s. 96.

72. Id. at s. 100 . 
While the registration system affects common law rights in a way similar to a Torrens system of land registration, unlike a Torrens system, it does not guarantee title and does not compensate those who are injured through the operation of the system. Furthermore, no action may be commenced against the Registrar for any act or omission in the performance of the Registrar's duties. ${ }^{3}$ While the Crown is bound by the Act, registration of an instrument does not restrict any right or power of the Minister and does not derogate from the proprietary rights of the Crown. It is unclear whether this latter provision may extend to Crown agencies and corporations. ${ }^{74}$

\section{ROYALTIES}

Part VI of the CPRA provides the legislative framework for the government's new fiscal policy for the frontiers, designed to enhance the rewards from success rather than subsidizing effort. The basic royalty of $10 \%$ of oil and gas produced and the progressive incremental royalty of $40 \%$ of net profits established under the Canada Oil and Gas Act will be replaced by a new royalty regime. The nature, rates, method of calculation of this royalty, deductions and exceptions, as well as other technical matters, are to be prescribed by the regulations. ${ }^{35}$ While the details of the new fiscal regime have yet to be promulgated, it is the government's announced intention to make the oil and gas tax regime more profit sensitive to take into account the high costs and long lead times involved in frontier exploration and development. Changes to the regime are a costless fiscal initiative to encourage such developments. Since the Atlantic Accord has transferred the responsibility for establishing royalties and taxes for the Newfoundland and Labrador offshore to the government of that province in accordance with the federal policy of shared management, the frontier royalty regime announced by the Minister of Energy, Mines and Resources on October 30, 1985 will apply only to regions of the frontier that have not been transferred from the federal government. It was announced at that time that the basic and progressive incremental royalties would be replaced by a profit sensitive royalty that, prior to project "payout", would commence at a rate of $1 \%$ of gross revenues, rising to $5 \%$ in increments of $1 \%$ every 18 months. Following payout of initial investment, including a fair return on capital investment, the royalty will rise to $30 \%$ of net cash flow. The definition of "payout", including what constitutes a fair return on investment, is the subject of consultation with industry and provincial and territorial governments. The proposed regime was intended to be similar to the royalties levied by Alberta on high-cost oil sands and enhanced oil recovery projects.

The policy statement also announced the government's intention to implement a $25 \%$ Investment Royalty Credit, applicable to eligible frontier exploration well costs equal to or below five million dollars for new exploration wells. The credit is not to be transferable between areas of the frontier, however, and may be applied only against royalties otherwise

73. Id. at s. 99.

74. Id. at ss. 6,98 .

75. Id. at s. 55. 
payable within the region. The Minister also introduced a new $25 \%$ Exploration Tax Credit (ETC) to help bridge the gap between the expiration of the Petroleum Incentive Program on March 31, 1986 (with the grandfathering of certain exploration commitments on the frontier until the end of 1987) and the commencement of frontier development. The Exploration Tax Credit is a tax-based incentive that will be nondiscriminatory by location and ownership. It will be earned at a $25 \%$ rate on qualifying Canadian exploration expenses (CEE) incurred on or after December 1,1985 and before January 1, 1991 in respect of wells costing in excess of five million dollars. The incentive will only be applicable to exploration expenditures that are not eligible for Petroleum Incentive Program payments, either federally or under the Alberta program. The ETC will be of benefit to non-tax paying companies who will be able to apply for a refund of up to $40 \%$ of the portion of the credit not otherwise utilized in the year the credit is earned. Unclaimed balances not refunded will be available for use in accordance with existing investment tax credit rules which allow a seven year carryforward and a three year carryback.

Flow-through shareholders will earn the credit in respect.of qualifying expenses incurred by them. ETC claimed or refunded will reduce the cumulative CEE of a taxpayer in a manner similar to the reduction by the investment tax credit of the capital cost of an asset for capital cost allowance purposes. CEE available to be transferred to the Cumulative Offset Account and used to offset Petroleum and Gas Revenue Tax otherwise payable will be reduced, therefore, by the ETC that has been claimed or refunded.

Where more than one taxpayer incurs expenses pertaining to a well, participants will be allowed to allocate the expenses in a reasonable manner. For the purposes of earning the credit, qualifying Canadian exploration expenses incurred in respect of a well will be those expenses as described in subparagraphs 66.1(6)(a)(ii), (ii.1) and (ii.2) of the Income Tax Act other than Canadian exploration expenses that are not well specific, Canadian exploration and development overhead expenses, interest, financing and borrowing charges, and expenses that attract an incentive under PIP, APIP or any other similar program.

The Act contains numerous technical provisions relating to the payment of royalty. Each holder of a share in a production licence is liable for the payment of royalties, although it is unclear whether such a holder is liable for the whole amount of the royalty or only of its proportionate share. ${ }^{76}$ Where the interest owner of a production licence consists of two or more holders, the representative of the interest holders may be required by regulation to collect and remit royalty to the Crown and to file the appropriate returns. ${ }^{n}$

To avoid potential liability, specific procedures must be observed on voluntary or involuntary transmission of an interest in a production licence. Where a successor in title acquires a share in a production licence, the successor is jointly and severally liable with the predecessor for all royalties, interest and penalties payable to the Crown unless the successor

76. Id.

77. Id. at s. 58. 
has obtained prior to such an acquisition a certificate from the Minister certifying that either these amounts have been paid, security for their payment has been accepted or arrangements for payment have been made. Similarly, assignees, liquidators, administrators and executors of the holder of a share of a production licence must obtain a comparable certificate prior to the distribution of any property under their control belonging to the holder of a share in a production licence, not simply the share in the production licence. Failure to do so renders the person required to obtain the certificate personally liable for the unpaid royalties, interest and penalties. ${ }^{\text {" }}$

\section{DISCLOSURE OF INFORMATION}

Part IX of the Act contains detailed provisions with respect to confidentiality of information furnished to the federal government by interest owners. Generally, all information or documents provided for the purpose of the Act are privileged and may not be disclosed without the consent in writing of the person who provided it. These restrictions do not, of course, apply to documents registered under the registration system provisions of Part VIII of the Act. The confidentiality provisions are limited, however, since information gathered under the Act may be disclosed to the government of a province or organization representing aboriginal peoples or pursuant to an agreement respecting resource management and revenue sharing between the federal government and a province or aboriginal peoples. The recipient of such information is also bound by the confidentiality provisions of the Act.

The Act allows the timed release of certain information relating to exploration and development programs. Timing of the release is generally a function of the information's commercial value, so that the more valuable the information, the longer the release time. For example, information and documentation with respect to an exploratory well is released two years after the well termination date, while delineation and development wells are the later of 90 days after the well termination date of the delineation or development well or two years after the well termination date of the relevant exploratory well."

\section{ARBITRATION}

\section{A. SURFACE ACCESS}

As in most jurisdictions, the pre-eminence of the mineral owner's right of access to work minerals has been altered by the provisions of section 102 of the Act which provides that where a person lawfully occupies the surface of frontier lands, no person acting under an interest may enter those lands without the consent of the occupier or without an order for entry from an arbitrator under an arbitration conducted in accordance with the regulations. 
[VOL. XXV, NO. 1

\section{B. OPERATING AGREEMENTS}

The regulations may authorize the Minister to order arbitration for disputes of a prescribed class between interest holders in respect of operations conducted on frontier lands for which an operating agreement is not in force or was made prior to March 5, 1982. These provisions are felt to be necessary because of the problems resulting from the imposition of the Canada Oil and Gas Act to existing rights. The order of an arbitrator will be binding on all interest holders from the date specified and will be deemed to be incorporated into the terms and conditions of the interest." However, future operating agreements must be negotiated between the parties.

\section{CANCELLATION OF RIGHTS}

The Minister's ability to cancel an interest or a share of an interest is retained under the Canada Petroleum Resources Act. Where the Minister has reason to believe that an interest owner or holder is failing to meet any requirement of the Act or of the Oil and Gas Production and Conservation Act, he or she may give a minimum 90 days' notice requiring compliance. Failure to comply with the notice may lead to cancellation of the interest, subject to the hearing and judicial review provisions of section 106. ${ }^{82}$

\section{HEARING AND JUDICIAL REVIEW}

One of the most conspicuous features of the Canada Oil and Gas Act was the wide discretionary powers reserved to the Minister. The scope of this discretion gave rise to concerns that it generated uncertainty and could be exercised unreasonably and preferentially. While there existed review provisions, the protections offered by them were dubious, since the hearing provided for was before the Minister who was the sole judge of the exercise of his or her discretionary power. The right to appeal to the Federal Court of Appeal was restricted to the narrow grounds provided by section 28 of the Federal Court Act of abuse of natural justice, errors in law or erroneous findings of fact made in a perverse or capricious manner or without regard to the evidence. Given the wide discretionary power of the Minister, it would be difficult under the Canada Oil and Gas Act to establish any error of law or violation of natural justice.

The Canada Petroleum Resources Act has limited the scope of the Minister's discretion through the repeal of provisions which allowed the issuance of production and disposition orders, designation of an operator and required drilling on commercial discoveries. While significant discretionary powers have been retained in the hands of the Minister, the review process has been improved through the substitution of a hearing before the Oil and Gas Committee established under the Oil and Gas Production and Conservation Act for the hearing previously conducted by the Minister. Section 106 applies to the issuance of drilling and development orders, the amendment or revocation of significant and commercial discovery declarations, approvals of transfers of shares in production licences and

81. Id. at ss. 103, 104.

82. Id. at s. 105. 
cancellation of rights for default. It requires the Minister, 30 days prior to making any order or decision or taking any action which the Act provides is subject to the hearing and judicial review provisions, to give notice in writing to the persons directly affected. Such persons may request within the 30-day period a hearing before the Committee, at the conclusion of which the recommendations of the Committee are submitted to the Minister together with the evidence taken. The Committee's recommendations are not binding on the Minister, however, who is required only to consider them and to make available to the person affected the reasons for a decision. As was the case under the Canada Oil and Gas Act, the Minister's decision is then subject to review by the Federal Court of Appeal under the narrow grounds provided in section 28 of the Federal Court Act.

\section{TRANSITIONAL}

The Canada Petroleum Resources Act, like the Canada Oil and Gas Act, is intended to replace most existing oil and gas rights that may have become vested in frontier lands prior to coming into force of the Act. As is the case under the COGA, a former interest owner will receive no compensation for any adverse effect that the Act may have upon those interests. ${ }^{.3}$ Exploration agreements entered into, or for which negotiations were completed, under the Canada Oil and Gas Act are for the purposes of the CPRA referred to as exploration licences, but have effect in accordance with their own terms and conditions. The few production licences granted under the COGA are deemed to be production licences issued under the Act. ${ }^{24}$ In the case of former permits and leases, special renewal permits or exploration agreements under the Canada Oil and Gas Land Regulations, the transitional provisions of the COGA are continued."s

\section{CONCLUSION}

The Canada Petroleum Resources Act is a positive legislative initiative in an area that has been of concern to the oil and gas industry. The decision to establish a competitive, non-discriminatory legislative and regulatory environment for frontier lands will attract more capital for the evaluation of Canada's oil and gas potential than otherwise would have been the case. This feature together with elimination of the Crown share and limitation of the extraordinary Ministerial powers previously applicable to exploration and production will establish a more stable and fair management regime. 